\title{
NIEMIECKIE UGRUPOWANIA POLITYCZNE WOBEC KRYZYSU UCHODŹCZEGO
}

\author{
Agnieszka Nitszke \\ Uniwersytet Jagielloński \\ Instytut Nauk Politycznych i Stosunków Międzynarodowych \\ Katedra Studiów nad Procesami Integracyjnymi \\ e-mail: agnieszka.nitszke@uj.edu.pl
}

\begin{abstract}
Streszczenie. Republika Federalna Niemiec (RFN) wypracowała model integracji i asymilacji uchodźców i imigrantów zarobkowych, który przez dziesięciolecia stanowił wzór dla innych państw europejskich i Unii Europejskiej (UE). Było to możliwe dzięki konsensusowi pomiędzy głównymi siłami politycznymi w kraju, które, mimo naturalnej alternacji władzy, nie podważały głównych założeń zarówno polityki zagranicznej, jak też wewnętrznej, w tym kwestii podejścia do imigrantów. Sytuacja uległa zmianie po 2011 r. i wydarzeniach w Afryce Północnej, zwanych arabską wiosną, których konsekwencją stał się masowy napływ uchodźców i imigrantów do Niemiec. W artykule przeanalizowane zostaną stanowiska głównych partii politycznych w odniesieniu do kryzysu uchodźczego.
\end{abstract}

Slowa kluczowe: Niemcy; polityka imigracyjna; kryzys uchodźczy; arabska wiosna; niemieckie partie polityczne

\section{WSTĘP}

Polityki uchodźcza i imigracyjna stanowią aktualnie jedną z głównych kwestii w debacie publicznej większości państw europejskich, a także Unii Europejskiej (UE) jako organizacji międzynarodowej zrzeszającej 28 państw członkowskich ${ }^{1}$. Polityki te, jak niewiele innych, wzbudzają duże kontrowersje, a spór wokół nich przebiega wzdłuż wielu podziałów socjopolitycznych ${ }^{2}$ i nie poddaje Brexitu.

1 Wliczając Wielką Brytanię, która w czerwcu 2017 roku rozpoczęła negocjacje w sprawie tzw.

2 Koncepcja podziałów socjopolitycznych jest jednym z podstawowych pojęć w politologii. Założeniem koncepcji jest istnienie obiektywnych podziałów społecznych, np. wynikających z miejsca zamieszkania (miasto - wieś), wieku, wykształcenia itp., oraz wynikających z nich potrzeb i oczekiwań politycznych, które są agregowane i realizowane przez partie polityczne. S.P. Lipset, S. Rokkan, Party systems and voter alignments: cross-national perspectives, The Free Press, New York 1967. 
się łatwej analizie. Republika Federalna Niemiec (RFN), jako jedno z pierwszych państw zachodnioeuropejskich, podjęła temat polityki imigracyjnej i uczyniła z niego kluczową kwestię społeczną i gospodarczą. Wynikało to przede wszystkim z wyzwań, przed którymi stanęła szybko rozwijająca się gospodarka zachodnioniemiecka w latach 60 . XX wieku i deficyt siły roboczej. W kolejnych dekadach doszły także inne przesłanki natury politycznej, które spowodowały, że Niemcy były wybierane przez uchodźców i imigrantów zarobkowych, jako miejsce docelowe. Przyczyniły się do tego zasadniczo dwie kwestie: po pierwsze, chęć wzmocnienia przez RFN swojej pozycji na arenie międzynarodowej, poprzez aktywne zaangażowanie w budowanie i utrzymanie ładu i pokoju na świecie, czemu miał służyć udział niemieckich misji zbrojnych i humanitarnych w toczących się konfliktach, a w konsekwencji także pomoc ofiarom tych konfliktów w formie azylu. Po drugie, perspektywiczna polityka demograficzna w obliczu ujemnego przyrostu naturalnego wśród ludności rdzennej i w konsekwencji procesu starzenia się społeczeństwa, czego efektem może być deficyt pracowników oraz coraz większe obciążenia dla systemu emerytalnego i służby zdrowia.

Niemiecka polityka wewnętrzna przez dekady charakteryzowała się dużą stabilnością. Ramy tamtejszego systemu politycznego wyznaczały dwie stałe: Ustawa Zasadnicza z 1949 r. z zasadą konstruktywnego wotum nieufności oraz „zamrożony” system partyjny. Drugi faktor uległ zmianie po zjednoczeniu Niemiec w 1990 r., kiedy na scenie politycznej znaczenie zaczęły odgrywać nowe siły polityczne i doszło do „odmrożenia” systemu partyjnego. Do dotychczas wiodących partii - Unii Chrześcijańsko-Demokratycznej (niem. Christlich Demokratische Union Deutschlands, CDU) / Unii Chrześcijańso-Społecznej (niem. Christlich-Soziale Union in Bayern, CSU), Socjaldemokratycznej Partii Niemiec (niem. Sozialdemokratisce Partei Deutschlands, SPD) oraz Wolnej Partii Demokratycznej (niem. Freie Demokratische Partei, FPD) dołączyły Partia Zielonych/ Związek 90 (niem. Die Grüne / Bündnis 90) ${ }^{3}$, Partia Demokratycznego Socjalizmu (niem. Partei des Demokratischen Sozialismus, PDS) przekształcona w 2005 r. w Lewicę (niem. Die Linke). W ostatnich latach pojawiła się nowa siła polityczna zyskująca coraz większe poparcie - Alternatywa dla Niemiec (niem. Alternative für Deutschland, AfD). Interesującym zjawiskiem na niemieckiej scenie politycznej jest także ruch społeczny PEGIDA (niem. Patriotische Europäer gegen die Islamisierung des Abendlandes, pol. Patriotyczni Europejczycy przeciw Islamiza-

3 Zieloni/Związek 90 wywodzi się z ekologicznego ruchu społecznego zainicjowanego na przełomie lat 60. i 70. XX wieku w RFN. Z czasem doszło do instytucjonalizacji ruchu i przekształcenia go w partię polityczną - Zieloni, która swój pierwszy sukces na arenie federalnej osiągnęła w $1983 \mathrm{r}$. W 1990 r. doszło do połączenia struktur zachodnioniemieckich Zielonych z wschodnioniemiecką partią Związek 90/Zieloni. W 1998 r. Zieloni/Związek 90 po raz pierwszy w historii utworzyli rząd koalicyjny na szczeblu federalnym z SPD. Koalicja została utrzymana także po kolejnych wyborach w $2002 \mathrm{r}$. Było to formalnym potwierdzeniem zmiany niemieckiego systemu partyjnego - z modelu dwu-i-półpartyjnego w model umiarkowanie wielopartyjny. K. Sobolewska-Myślik, Partie i systemy partyjne na świecie, PWN Warszawa 2004. 
cji Zachodu), który często bywa określany jako ksenofobiczny i antyimigrancki. Na obrzeżach systemu partyjnego i politycznego działają także partie radykalne, które jednak nie mają realnego wpływu na politykę państwa, przez co nie będą poddane analizie $\mathrm{w}$ artykule ${ }^{4}$.

Zarówno w niemieckiej jak i polskiej literaturze politologicznej w ostatnich latach pojawił się szereg interesujących publikacji dotyczących polityki imigracyjnej Niemiec i jej ewolucji ${ }^{5}$, jednak analiza tam zawarta najczęściej dotyczy rozwiązań systemowych, bez uwzględnienia mechanizmów politycznych prowadzących do wypracowania decyzji politycznych na poziomie partii i ruchów społecznych. Niniejszy artykuł stanowi zatem uzupełnienie stanu badań o prezentację i analizę programów partii politycznych, które kształtują politykę w zakresie azylu i imigracji.

Celem niniejszego artykułu jest odpowiedź na następujące pytania badawcze: P1 Czy kryzys imigracyjny zapoczątkowany wydarzeniami arabskiej wiosny wpłynął zasadniczo na zmianę polityki imigracyjnej poszczególnych partii politycznych w Niemczech?; P2 Czy powstanie i działalność nowych partii i ruchów społecznych (antyimigranckich) wpływa na zmianę programów głównych partii niemieckich w zakresie azylu i imigracji?; P3 Czy konsensus w zakresie polityki azylowej i imigracyjnej między głównymi partiami politycznymi w Niemczech w wyniku kryzysu imigracyjnego dobiegł końca?; P4 Czy wielka koalicja CDU/CSU - SPD jest zdolna wypracować spójne podejście w dziedzinie azylu i imigracji?

\section{UWARUNKOWANIA NIEMIECKIEJ POLITYKI AZYLOWEJ I IMIGRACYJNEJ}

Niemiecka polityka azylowa i imigracyjna jest warunkowana przez następujące elementy: zobowiązania prawnomiędzynarodowe, w szczególności zasady wynikające z prawa UE; doświadczenia w zakresie imigracji zarobkowej do RFN po II wojnie światowej; aktualne wyzwania demograficzne oraz konsensualną kulturę polityczną kraju.

${ }^{4}$ W wyborach w 2013 r. wystartowały 34 partie polityczne, z czego większość stanowiły tzw. partie zeroprzecinowe (niem. Null-Komma-Parteien), co odnosi się do wyników, które te partie uzyskują - zwykle nie przekraczając 1 procenta oddanych głosów. Dużą część tego typu ugrupowań stanowią partie prawicowe bądź skrajnie prawicowe. M. Tujdowski, Alternatywne ruchy prawicowe w wyborach do Bundestagu, „Biuletyn Niemiecki” 2013, nr 40, http://fwpn.org.pl/assets/Publikacje/ Biuletyn_Niemiecki/BIULETYN_NIEMIECKI_NR_40.pdf, [dostęp 12.05.2016].

5 B. Simon, Deutschland als Einwanderungsland? Deutsche Migrationspolitik, Perspektiven für ein modernes Zuwanderungsgesetz, Grin Verlag Norderstedt 2003; Kämpfe um Migrationspolitik: Theorie, Methode und Analysen kritischer Europaforschung, Forschungsgruppe "Staatsprojekt Europa', Bielefeld 2014; V. Tomei, Europäisierung nationaler Migrationspolitik: eine Studie zur Veränderung von Regieren in Europa, Lucius\&Lucius Stuttgart 2001; M. Szaniawska-Schwabe, Polityka imigracyjna Republiki Federalnej Niemiec, „Przegląd Zachodni” 2009, nr 4, s. 3-29; M. Mazur-Rafał, Zmiana paradygmatu w niemieckiej polityce imigracyjnej w latach 1998-2004?: wnioski dla Polski, CEFMR Working Paper 2006, http://www.cefmr.pan.pl/docs/cefmr_wp_2006-02. pdf, [dostęp 12.06.2016]. 
$\mathrm{Na}$ forum UE, jak również w poszczególnych pastwach członkowskich, w tym Niemczech, trwa debata na temat charakteru kryzysu migracyjnego, z którym Europa mierzy się od 2011 r. Zasadnicze pytanie dotyczy statusu osób przybywających do Europy z Afryki Północnej i Bliskiego Wschodu - czy są to uchodźcy, czy imigranci zarobkowi? Odpowiedź na to pytanie decyduje o zasadach, które wobec takich osób zostaną zastosowane, a zatem także o rodzaju polityki - azylowej czy imigracyjnej. Rozróżnienie między tymi dwiema politykami ma ogromne znaczenie, również z punktu widzenia podmiotów, które podejmują decyzje. Procesy integracyjne w ramach UE spowodowały, że także część polityk wewnętrznych, niegdyś traktowanych jako wyłączna domena państw członkowskich, zaczęła podlegać wspólnotowym regulacjom. Na poziomie UE udało się dotychczas ujednolicić część przepisów i procedur w zakresie polityki azylowej, ${ }^{6}$ natomiast polityka imigracyjna nadal $\mathrm{w}$ większości pozostaje $\mathrm{w}$ gestii państw członkowskich, które decydują o kryteriach legalnego pobytu oraz prawach przyznawanych imigrantom. Polityka azylowa jest związana z wartościami, na których opiera się UE i które sprawiają, że Unia jest nie tylko wspólnotą gospodarczą, ale także coraz mocniej wspólnotą polityczną. Wartości humanitarne powodują, że Unia i jej państwa członkowskie udzielają pomocy i schronienia osobom znajdującym się w sytuacjach zagrożenia życia lub zdrowia z powodu toczących się konfliktów lub prześladowań na tle politycznym, religijnym, narodowościowym i innym, w kraju ich pochodzenia lub aktualnego pobytu.

Charakter konfliktów w Afryce Północnej i na Bliskim Wschodzie powoduje, że często trudno jednoznacznie rozróżnić uchodźców od imigrantów zarobkowych, a proces weryfikacji dokumentów lub innych dowodów jest skomplikowany i długotrwały. Z tego względu UE, a w rzeczywistości państwa członkowskie, decydują się przyjmować wszystkie osoby i dopiero następczo decydować o ich statusie formalnoprawnym. Z tego względu, bez rozstrzygania o statusie osób przybywających do UE, można posłużyć się terminem neutralnym i określić wszystkie osoby jako migrantów.

Niemiecka polityka w zakresie zarządzania aktualnym kryzysem migracyjnym wpisuje się w szerszą debatę europejską, ale warto zwrócić uwagę, że niemiecki głos, ze względu na potencjał ekonomiczny i polityczny, na forum Unii jest szczególnie ważny. Niemiecki „cud gospodarczy” z przełomu lat 50. i 60. XX wieku spowodował, że państwo to z kraju emigracji stało się krajem imigracji ${ }^{7}$ Szybko rozwijający się przemysł ciężki generował zapotrzebowanie na siłę

6 A. Nitszke, Polityka azylowa Unii Europejskiej. Między idealizmem a realizmem, [w:] R. Kłosowicz, B. Szlachta, J.J. Węc (red.), Dylematy strategiczne XXI wieku. Wyd. Księgarnia Akademicka Kraków 2013, s. 353-365.

7 Warto nadmienić, że w okresie tuż powojennym do Niemiec powróciło około $10 \mathrm{mln}$. osób pochodzenia niemieckiego (tzw. przesiedleńcy). Część z nich nie znała języka lub posługiwała się jego różnymi dialektami, dodatkowo byli traktowani jako konkurencja na ograniczonym wówczas rynku pracy. Wszystko to nie ułatwiało ich asymilacji prowadząc niejednokrotnie do konfliktów społecznych [Szaniawska-Schwabe 2009]. 
roboczą. W tamtym czasie nisko wykwalifikowanych robotników, tzw. Gastarbeiterów, pozyskiwano głównie z Włoch, Jugosławii, Maroka, a także z Turcji. ${ }^{8}$ Niemcy podpisywały specjalne umowy - Porozumienia w sprawie rekrutacji, na podstawie których robotnicy przybywali do Niemiec, gdzie mieli zapewnione zatrudnienie, a także ubezpieczenia. $Z$ czasem część robotników zaczęła sprowadzać swoje rodziny, co poskutkowało koniecznością rozwinięcia polityki integracji i asymilacji imigrantów, w tym odpowiednich programów edukacyjnych. W okresie do 1990 r. sytuacja Gastarbeiterów była w dużej mierze warunkowana przepisami Ustawy o cudzoziemcach z 1965 r. ${ }^{9}$, która dawała urzędnikom prawo decydowania o prawie dalszego pobytu cudzoziemców i prawie podejmowania legalnego zatrudnienia. Niemniej pierwsze doświadczenia RFN z imigrantami zarobkowymi były pozytywne - dzięki nim gospodarka niemiecka mogła się rozwijać stając się najsilniejszą gospodarką Europy.

Od lat 90. XX wieku prognozy demograficzne wskazują, że w perspektywie kolejnych 50 lat Niemcy, podobnie jak wiele innych państw europejskich, staną przed nowym wyzwaniem - wyludnieniem. Minimalny przyrost naturalny na poziomie $0,1 \%$ aktualnie zapewniają głównie imigranci. Szacunki różnych instytucji (Eurostatu, Federalnego Urzędu Statystycznego) oraz organizacji międzynarodowych (ONZ) przewidują, że aby w 2050 r. liczba ludności Niemiec pozostała na dzisiejszym poziomie konieczny byłby napływ dodatkowych 17,8 mln imigrantów. ${ }^{10}$ Do tego należy dodać problem starzenia się społeczeństwa i zwiększających się obciążeń dla systemu opieki zdrowotnej i zabezpieczeń emerytalnych, w efekcie osoby czynne na rynku pracy będą zmuszone płacić $46 \%$ swoich zarobków na składki emerytalne oraz $25 \%$ na kasy chorych. ${ }^{11}$ Oczywiście należy pamiętać, że są to symulacje, które odnoszą się tylko do danych demograficznych i nie biorą pod uwagę zmian, które mogą nastąpić w strukturze gospodarki i charakterze produkcji. Niemniej dane te działają na wyobraźnię zarówno polityków, jak również zwykłych obywateli, powodując, że migranci nie są traktowani jako zagrożenie, lecz szansa na zachowanie ciągłości społeczeństwa.

Wypracowany w Niemczech po II wojnie światowej model konsensualnej polityki, wpisany w zasady Ustawy Zasadniczej z 1949 r., sprawia, że główne partie polityczne nastawione są na kooperację, a nie konfrontację. Oczywiście trzeba wziąć pod uwagę naturalne różnice w programach partii wywodzących się z różnych tradycji i odnoszących się do odmiennych ideologii i doktryn politycznych,

${ }^{8}$ M. Wojtan, Proces akcesji Polski do Unii Europejskiej w zakresie przepływu osób a doświadczenia Niemiec, Wydawnictwo Uniwersytetu Wrocławskiego, Wrocław 2004.

${ }^{9}$ Ausländergesetz der Bundesrepublik Deutschland vom 28. April 1965, Sammlung des Bundesrechts, Bundesgesetzbl. 111 2600-1

${ }^{10}$ M. Szaniawska-Schwabe, Polityka imigracyjna Republiki Federalnej Niemiec, „Przegląd Zachodni" 2009, nr 4, s. 3-29.

${ }^{11}$ Germany's population by 2050 . Results of the 11 th coordinated population projection, Federal Statistical Office, 2006, https://www.destatis.de/EN/Publications/Specialized/Population/ GermanyPopulation2050.pdf?_blob=publicationFile, [dostęp 12.05.2016]. 
niemniej w kwestiach zasadniczych dotyczących priorytetów polityki zagranicznej i wewnętrznej, różnice mają charakter szczegółowy, natomiast cele są wspólne. Konsensualno-integracyjna kultura polityczna Niemiec sprawia, że dotychczas, także w obszarze polityki azylowej i imigracyjnej, nie dochodziło do zasadniczych różnic pomiędzy partiami. Co więcej, do lat 90 . XX wieku za rządzenie krajem na przemian odpowiadały trzy obozy polityczne: chadecy (CDU/CSU), socjaldemokraci (SPD) oraz liberałowie (FDP), w tym najczęściej tworząc układy koalicyjne w różnej konfiguracji. ${ }^{12}$ Od połowy lat $90 . \mathrm{XX}$ wieku sytuacja zaczęła się zmieniać poprzez wzrost znaczenia nowych sił politycznych, w tym Zielonych czy Lewicy. Jednak dopiero ostatnie lata i kryzysy - gospodarczy i uchodźczy, spowodowały realne przemiany na niemieckiej scenie partyjnej i zerwanie $\mathrm{z}$ dotychczasową polityką konsensualną na rzecz modelu mieszanego - konsensualno-konfliktowego, ${ }^{13}$ w ramach którego prezentowane i realizowane są różne interesy społeczne.

\section{BUNDESTAG XVIII KADENCJI - PROGRAMY PARTII POLITYCZNYCH. UMOWA KOALICYJNA CDU/CSU - SPD}

22 września 2013 r. odbyły się wybory do Bundestagu XVIII kadencji. W tym czasie Unia Europejska borykała się z dwoma najpoważniejszymi od dziesięcioleci kryzysami - ekonomicznym oraz uchodźczym. Mimo iż ani jeden, ani drugi kryzys nie dotyczył bezpośrednio Niemiec, to ich pośrednie skutki wpływały na politykę wewnątrzkrajową. Kryzys ekonomiczny, i będący jego pochodną kryzys strefy euro, spowodował konieczność ratowania zadłużonych gospodarek, m.in. Grecji czy Hiszpanii, a koszty tych operacji w dużej mierze zostały pokryte przez rząd niemiecki, a co za tym idzie przez niemieckich podatników. Z kolei kryzys uchodźczy dotknął w pierwszej kolejności państwa południowe, w tym Włochy czy Grecję, do wybrzeży których napływali migranci z Afryki Północnej i Bliskiego Wschodu. Ówczesny koalicyjny rząd CDU/FDP, z kanclerz Angelą Merkel na czele, od początku prowadził otwartą politykę wobec uchodźców zachęcając do tego samego także rządy innych państw Unii Europejskiej. Temat polityki migracyjnej stał się zatem naturalnym elementem kampanii wyborczej, aczkolwiek, co warto zaznaczyć, nie był kwestią dominującą. ${ }^{14}$ Tradycyjnie w trakcie kampanii wyborczej główna rywalizacja rozgrywała się pomiędzy chadecją i socjaldemokracją. Wynik

${ }^{12}$ A. Nitszke, System partyjny Niemiec, [w:] B. Kosowska-Gąstoł (red.), Systemy partyjne państw Unii Europejskiej. Wydawnictwo UJ, Kraków 2010, s. 241-258.

${ }^{13}$ M. Sus, Kultura polityczna w Polsce $i$ w Niemczech, Interakcje. Leksykon komunikowania polsko-niemieckiego, 2014, http://www.polska-niemcy-interakcje.pl/articles/show/42, [dostęp 12.05.2016].

${ }^{14}$ K. Frymark, Znaczenie polityki zagranicznej dla niemieckich partii w kontekście wyborów, „Biuletyn Niemiecki” 2013, nr 38, http://fwpn.org.pl/assets/Aktualnosci/2013/2013_07_30_Biuletyn/ BIULETYN_NIEMIECKI_NR_38.pdf, [dostęp 12.05.2016]; P. Kubiak P., Wybory do Bundestagu z 22 września 2013 roku. Analiza i konsekwencje, „Przegląd Zachodni’2014, nr 1, s. 13-44. 
wyborów z jednej strony nie były zaskoczeniem - zwycięstwo CDU przewidywało wiele sondaży przedwyborczych, $\mathrm{z}$ drugiej natomiast strony nikt nie spodziewał się klęski liberałów, bądź co bądź partii współrządzącej, która zaledwie cztery lata wcześniej odnotowała najlepszy w historii wynik zdobywając ponad 14,5\% głosów, a tym razem nie przekroczyła pięcioprocentowego progu wyborczego i nie weszła do nowego Bundestagu. To spowodowało, że chadecy byli zmuszeni do zawarcia nowej koalicji z socjaldemokratami, czyli tzw. wielkiej koalicji.

Tab. 1. Wyniki wyborów do Bundestagu XVIII kadencji

\begin{tabular}{|c|c|c|}
\hline \multirow{2}{*}{ Partia } & \multicolumn{2}{|c|}{ Wyniki } \\
\cline { 2 - 3 } & $\%$ & Liczba mandatów \\
\hline CDU/CSU & 41,5 & 311 \\
\hline SPD & 25,7 & 192 \\
\hline Lewica & 8,6 & 64 \\
\hline Zieloni & 8,4 & 63 \\
\hline FDP & 4,8 & - \\
\hline AfD & 4,7 & - \\
\hline
\end{tabular}

Źródło: Bundestagswahl 2013. Ergebnisse der Wahl zum 18. Deutschen Bundestag, Der Bundeswahlleiter, https://www.bundeswahlleiter.de/de/bundestagswahlen/BTW_BUND_13/veroeffentlichungen/BTW2013_ Erg-Flyer_Internet.pdf, [dostęp: 16.01.2016].

Program wyborczy chadeków to w zasadzie połączone programy dwóch partii - CDU i CSU ${ }^{15}$, które mimo iż w większości kwestii są zbieżne, to występują pomiędzy nimi także różnice, zwłaszcza w sprawach światopoglądowych, ale także w niektórych aspektach polityki zagranicznej. Przed wyborami w 2013 r. chadecy przedstawili program wyborczy pt. „Razem z sukcesem dla Niemiec. Program rządowy 2013-2017", ${ }^{16} \mathrm{w}$ którym kwestie azylu i imigracji znalazły się na stosunkowo odległym miejscu - dopiero w punkcie czwartym zatytułowanym „Wzmocnić spójność Niemiec” w podpunkcie „Różnorodność wzbogaca - tworzyć kulturę powitania". ${ }^{17} \mathrm{Na}$ wstępie tego fragmentu programu zaznaczono bardzo wyraźnie, że Niemcy były i są państwem otwartym na migrantów, którzy wzbogacają kraj, przyczyniając się do budowania dobrobytu, ale także różnorodności kulturowej. W dokumencie mowa jest o konieczności stworzenia systemu, który zagwarantuje niemieckiej gospodarce dopływ fachowców, ale także stworzy warunki integracji

${ }^{15}$ CSU w kwestiach gospodarczych jest bardziej socjalna od CDU, a z kolei w kwestiach światopoglądowych bardziej konserwatywna od swej bliźniaczej partii. Program chadeków powstawał przez kilka miesięcy i był szeroko konsultowany z wyborcami i członkami partii, dzięki czemu odzwierciedla najważniejsze i najbardziej aktualne problemy społeczne. M.M. Kosman, Programy niemieckich partii politycznych w wyborachdo Parlamentu Europejskiego w 2014 roku. Wybrane aspekty, „Rocznik Integracji Europejskiej” 2014, nr 8(14), s. 285-302.

${ }^{16}$ Gemeinsam erfolgreich für Deutschland. Regierungsprogramm 2013-2017, 2013, https://www.cdu.de/sites/default/files/media/dokumente/regierungsprogramm-2013-2017-langfassung-20130911.pdf, [dostęp18.06.2016].

${ }^{17}$ Ibidem. 
i rozwoju zawodowego osobom, które przybywają do Niemiec nie posiadając żadnych kwalifikacji zawodowych. Oferta chadeków względem imigrantów nie jest jednak bezwarunkowa. Migranci, którzy decydują się przybyć do Niemiec, powinni przede wszystkim akceptować wartości i zasady obowiązujące w niemieckim społeczeństwie, a do tego konieczna jest znajomość języka i kultury. Zadeklarowano także pomoc dla uchodźców, w tym przyjmowanie osób ubiegających się o azyl z państw trzecich. Wskazano przy tym, że odpowiednie rozwiązania muszą być przyjęte na poziomie Unii Europejskiej, tak by w przyszłości wyeliminować sytuacje, w których imigranci kierują się kryteriami ekonomicznymi i wybierają Niemcy, jako kraj docelowy ze względu na wysoki poziom pomocy i zabezpieczeń socjalnych. W programie chadeków widać wyraźnie pozytywny stosunek do migrantów, jednak obwarowany kilkoma zastrzeżeniami, wśród których naczelne miejsce zajmuje „promowanie i żądanie integracji”. Zdaniem chadeków jest to także sposób na eliminowanie negatywnych zjawisk, takich jak radykalizacja religijna, w szczególności islamska. Elektorat CDU i CSU to przede wszystkim rodowici Niemcy, o poglądach centroprawicowych, głównie starsi - ponad 65\% wyborców CDU przekroczyło 45 lat, z czego $40 \%$ to osoby powyżej 60. roku życia. W przypadku CSU statystyki przedstawiają się podobnie. ${ }^{18}$ To powoduje, że chadecy, mimo deklarowanej „kultury powitania” (niem. Willkommenskultur), zachowują pewną ostrożność $\mathrm{w}$ zakresie praw przyznawanych imigrantom, w tym prawa wyborczego czy obywatelstwa - wykluczają możliwość posiadania przez imigrantów podwójnego obywatelstwa, a także udziału (biernego i czynnego) w wyborach, tak na szczeblu federalnym jak i krajowym.

SPD, podobnie jak chadecja, w programie wyborczym zatytułowanym „To MY decyduje" (niem. Das Wir entscheidet) ogłoszonym 14 kwietnia 2013 r. główny nacisk położyła na kwestie związane z polityką wewnętrzną, w tym głównie sprawy ekonomiczne. ${ }^{19}$ Zagadnienia polityki migracyjnej, w tym azylowej, znalazły się w trzecim rozdziale programu poświęconym edukacji, równouprawnieniu i współżyciu w nowoczesnym społeczeństwie. Już samo to wskazuje, że socjaldemokraci nie rozdzielają spraw migracji od kwestii ogólnospołecznych. W programie podkreślono, że należy zastąpić termin „integracja” nowym określeniem „uczestnictwo". Oczywiście nie tylko o słowa chodzi, ale przede wszystkim podejście do migrantów - ich obowiązków i ich praw w Niemczech. SPD uważa, że nadszedł czas, by Niemcy zrobiły kolejny krok i z kraju imigracji (niem. Einwanderungsland) stały się państwem naturalizacji (niem. Einbürgerungsland). Dzięki takiemu podejściu, zdaniem SPD, możliwe będzie uniknięcie wielu problemów z prawidłowym funkcjonowaniem imigrantów w społeczeństwie niemieckim.

${ }^{18}$ Altersstruktur der Wähler der CDU bei der Bundestagswahl 2005, http://de.statista.com/ statistik/daten/studie/1496/umfrage/altersstruktur-der-waehler-der-cdu-bundestagswahl-2005/, [dostęp 18.06.2016].

${ }^{19}$ Das Wir entscheidet. Regierungsprogramm 2013-2017, www.spd.de_linkableblob_96686 data_20130415-regierungsprogramm-2013-2017.pdf, [dostęp 12.05.2016]. 
SPD wyraźnie opowiada się za przyznaniem imigrantom biernego i czynnego prawa wyborczego $\mathrm{w}$ wyborach komunalnych po pięcioletnim okresie pobytu w Niemczech. Także w zakresie obywatelstwa SPD prezentuje inną optykę niż chadecja. Socjaldemokraci uważają, że należy zmienić niemieckie prawo i zezwolić na podwójne obywatelstwo, zwłaszcza dla dzieci imigrantów urodzonych w Niemczech, które powinny mieć zagwarantowane obywatelstwo niemieckie i w momencie osiągnięcia pełnoletniości możliwość zachowania obywatelstwa niemieckiego i obywatelstwa kraju rodziców, jeżeli wyrażą taka wolę. W odniesieniu do polityki azylowej SPD prezentuje otwartą postawę ukierunkowaną na pomoc ofiarom wojen, konfliktów prześladowań i przemocy, szczególnie kobietom i dzieciom. Socjaldemokraci zaznaczają, że konieczne jest ujednolicenie procedur azylowych w całej UE, a także solidarność państw członkowskich w zakresie zarządzania kryzysami migracyjnymi.

Lewica, na tle innych partii niemieckich, wyróżnia się największym radykalizmem. Stanowisko partii w odniesieniu do migracji i azylu zawarte zostało w programie wyborczym pt. „100\% socjalny” przyjętym 16 czerwca 2013 r. ${ }^{20}$ Jako jedyna partia parlamentarna Lewica optuje za przyznaniem biernego i czynnego prawa wyborczego w wyborach komunalnych, krajowych i federalnych wszystkim imigrantom zamieszkującym na stałe w Niemczech. Dopuszcza również możliwość posiadania podwójnego obywatelstwa. Co więcej, partia odrzuca dotychczasową politykę migracyjną i integracyjną, określając ją jako „neokolonialną", gdyż sterowanie migracją i system selektywnego doboru migrantów jest, ich zdaniem, sprzeczny z prawami człowieka. ${ }^{21}$ Znajduje to także wyraz w tytule rozdziału programu poświęconego migracji: „Demokracja dla wszystkich, którzy tutaj żyją. Jednakowe prawa dla migrantów". W praktyce ma to oznaczać nie tylko prawa polityczne, ale przede wszystkim prawa socjalne, takie jak dostęp do edukacji, rynku pracy, czy systemu ochrony zdrowia. Lewica postuluje także zmiany w zakresie polityki azylowej, tak by nie pozostawiać potrzebujących bez odpowiedniego wsparcia. W tym celu konieczne są zmiany na poziomie UE i większa solidarność, ale też wrażliwość państw członkowskich. Ciekawym postulatem partii w tym zakresie jest likwidacja unijnej agencji Frontex odpowiadającej za ochronę granic zewnętrznych UE.

Kolejna niemiecka partia prezentująca otwarty stosunek do migrantów i uchodźców to Zieloni. Partia ta tradycyjnie wspiera politykę wielokulturowości. W programie Zielonych przyjętym 29 kwietnia 2013 r. zatytułowanym „Czas na zieloną zmianę" kwestie praw migrantów i uchodźców znalazły się w rozdziale pt. „Wzmocnienie praw obywatelskich”. ${ }^{22} \mathrm{~W}$ wielu punktach program Zielonych

${ }^{20} 100 \%$ sozial. Die Linke. Wahlprogramm zur Bundestagswahl 2013, www.die-linke.de_fileadmin_download_wahlen2013_bundestagswahlprogramm_bundestagswahlprogramm2013-langfassung.pdf, [dostęp 12.05.2016].

${ }^{21}$ Ibidem.

${ }^{22}$ Zeit für den grünen Wandel, www.gruene.de_fileadmin_user-upload_Dokumente_Gruenes -Bundestagswahlprogramm-2013.pdf, [12.05.2016]. 
jest zbieżny z postulatami Lewicy, aczkolwiek są pewne różnice. Najważniejsza dotyczy prawa wyborczego - Zieloni są za przyznaniem prawa wyborczego migrantom w wyborach lokalnych, o innych szczeblach program nie wspomina. Podobnie jak Lewica uważają, że należy odejść od tradycyjnego pojmowania „,integracji” migrantów na rzecz ich pełnego włączenia do systemu społecznogospodarczego, poprzez lepszy dostęp do rynku pracy i zniesienie barier dyskryminujących przybyszów, w tym np. nieuznawanie kwalifikacji zawodowych zdobytych w krajach pochodzenia. W odniesieniu do uchodźców Zieloni podkreślają konieczność niesienia pomocy ludziom z terenów ogarniętych konfliktami, uznając to za obowiązek moralny. Krytyka Zielonych jest skierowana na unijne rozwiązania, w tym działalność agencji Frontex oraz regulacje zawarte w porozumieniu Dublin II, które mówi, że za rozpatrzenie wniosku o udzielenie azylu odpowiada jedno państwo i co do zasady powinno to być państwo pierwszego kontaktu [Dublin II]. W obliczu presji migracyjnej okazało się, że porozumienie nie działa, a migranci byli przepuszczani z południa Europy przez kolejne granice do państw Europy Północnej. Zieloni wskazują na potrzebę stworzenia spójnego, sprawiedliwego i opartego o zasadę solidarności systemu azylowego UE.

Postawa FDP w zakresie migracji jest zbliżona do chadeków, co nie powinno dziwić, gdyż program liberałów zatytułowany „Program obywateli” został przedstawiony 5 maja 2013 r., czyli w czasie, gdy FDP współtworzyła koalicję rządzącą z CDU/CSU. Liberałowie opowiadają się za przyznaniem prawa wyborczego imigrantom w wyborach lokalnych po pięcioletnim okresie legalnego pobytu. Uważają także, że imigranci powinni mieć prawo zachowania obywatelstwa państwa pochodzenia, co nie powinno mieć wpływu na przyznanie im obywatelstwa niemieckiego. Pragmatyzm FDP przejawia się w praktycznych aspektach życia imigrantów w Niemczech. Partia uważa, że jednym z warunków powodzenia integracji migrantów w społeczeństwie niemieckim jest usamodzielnienie, rozumiane jako możliwość samodzielnego utrzymania siebie i swojej rodziny, a zatem możliwość podjęcia od samego początku pobytu legalnej pracy. FDP zwraca uwagę na konieczność pełnej integracji migrantów, ale przy możliwości zachowania przez nich tożsamości kulturowej i religijnej. Receptą na radykalizację środowisk muzułmańskich ma być możliwość nauczania religii islamskiej w szkołach publicznych, gdzie będzie zapewniona kontrola nad prezentowanymi tam treściami. Prawa uchodźców FDP wiąże z ogólnymi prawami człowieka i z tego względu uważa, że Niemcy mają obowiązek udzielenia pomocy osobom zagrożonym [FDP. Bürgerprogramm 2013]..$^{23}$

Nowym fenomenem na niemieckiej scenie politycznej jest partia pod nazwą Alternatywa dla Niemiec. Ugrupowanie to powstało w proteście przeciwko polityce rządzącej koalicji, a nawet szerzej - przeciwko polityce wszystkich dotychczas rządzących partii, tzw. mainstreamowych. AfD w kampanii wyborczej

${ }^{23}$ FDP. Bürgerprogramm 2013, www.fdp.de_files_408_Buergerprogramm-A5-Online-2013-07-23.pdf, [dostęp 12.05.2016]. 
w 2013 r. koncentrowała się głównie na kryzysie ekonomicznym, w tym kryzysie w strefie euro i rozwiązaniom proponowanym i wdrażanym przez rząd niemiecki i instytucje UE. Niemniej także problem uchodźców i migrantów stał się jednym $\mathrm{z}$ tematów kampanii AfD. Partia przedstawiła skrajny program w odniesieniu do kryzysu migracyjnego i samego problemu przyjmowania migrantów. Alternatywa jest przeciwna przyznawaniu jakichkolwiek praw politycznych imigrantom. Wyklucza możliwość posiadania podwójnego obywatelstwa, jak również prawa wyborczego, nawet w wyborach lokalnych. AfD, rozumiejąc procesy demograficzne, nie jest całkowicie przeciwna napływowi migrantów. Polityka rządu w tym zakresie, ich zdaniem, powinna być ukierunkowana na zabezpieczenie interesów Niemiec, a zatem powinna to być polityka selektywna zapewniająca napływ wykwalifikowanej siły roboczej, która uzupełni deficyty na niemieckim rynku pracy. Również w odniesieniu do kwestii azylu AfD prezentuje postawę odmienną od pozostałych partii, uważając, że cały system jest wadliwy i prowadzi do nadużyć. Partia postuluje zaostrzenie prawa azylowego, przy czym, jak zostało nadmienione wcześniej, polityka ta została uwspólnotowiona, a zatem przepisy musiałyby zostać zmienione na poziomie unijnym. AfD uważa, że należy postawić ultimatum: „,integracja albo deportacja”, a osoby, które wejdą w konflikt z prawem powinny być bezwzględnie wydalane z kraju. Aby złagodzić mocno negatywny wydźwięk tych postulatów, Alternatywa opowiada się za szerszą współpracą z państwami trzecimi w zakresie polityki powrotów migrantów. ${ }^{24}$

W kontekście debaty nad polityką migracyjną i azylową warto wspomnieć o ruchu społecznym PEGIDA, który wprawdzie w wyborach nie brał udziału, jednak jego postulaty i działania mają realny wpływ na konkurencję polityczną i mogą mieć znaczenie podczas kolejnych wyborów do Bundestagu w 2017 r. Sam ruch powstał w październiku 2014 r. pod wpływem kryzysu migracyjnego i polityki otwartości rządu Angeli Merkel. ${ }^{25} \mathrm{~W}$ mediach PEGIDA najczęściej bywa przedstawiana w sposób uproszczony, jako ruch społeczny skierowany przeciwko „muzułmańskiej ekspansji” w Niemczech. ${ }^{26}$ Faktycznie PEGIDA opowiada się przeciwko radykalnemu islamowi, a nie samym muzułmanom. W odniesieniu do problemu migrantów i uchodźców PEGIDA prezentuje postawę stanowczą, aczkolwiek nie wrogą. W oficjalnych wystąpieniach liderów ruchu mowa jest o konieczności stosowania istniejących przepisów, tak by można było wydalać $\mathrm{z}$ terytorium Niemiec osoby, które wejdą w konflikt z prawem. W odniesieniu do uchodźców PEGIDA zauważa, że ich przyjmowanie jest „ludzkim obowiązkiem”. Państwo powinno zaś gwarantować lepszą opiekę, m.in. ze strony pracowników

${ }^{24}$ A. Gauland, Thesen zur Außenpolitik, 2013, http://www.alternativefuer.de/thesenpapier-aussenpolitik/, [dostęp 12.06.2016].

${ }^{25}$ A. Pfahl-Traughber, Pegida - eine Protestbewegung zwischen Ängsten und Ressentiments. Eine Analyse aus der Sicht der Bewegungs- Extremismus- und Sozialforschung, Bundeszentrale für politische Bildung, 2015, http://www.bpb.de/politik/extremismus/rechtsextremismus/200901/ pegida-eine-protestbewegung-zwischen-aengsten-und-ressentiments, [dostęp 12.05.2016].

${ }^{26}$ Ibidem. 
opieki społecznej, tak by nie powstawały zamknięte społeczności, w których obowiązują inne normy i prawo, np. religijne. PEGIDA, jako typowy ruch społeczny, angażuje obywateli głównie poprzez organizację masowych demonstracji, gdzie umiarkowane hasła liderów są konfrontowane z postulatami protestujących, co czasem wymyka się spod kontroli organizatorów. ${ }^{27}$ Choć należy zaznaczyć, że także część liderów, w tym jeden z założycieli - Lutz Bachmann, posługuje się antyimigrancką retoryką. Na stronie PEGIDY na jednym z portali społecznościowych Bachmann określił imigrantów słowami: „,hołota”, „,robactwo”, „odpady”. ${ }^{28}$ Atmosfera wieców przyciąga uwagę mediów, przez co postulaty - zarówno oficjalne jak i spontaniczne, trafiają do szerokiego grona obywateli i polityków, którzy muszą się często do nich ustosunkowywać, a co za tym idzie także korygować oficjalne założenia programowe partii. W ten sposób teoria polityczno-partyjna często zderza się z rzeczywistością społeczną.

Mimo, iż w wielu punktach programy chadeków i socjaldemokratów różniły się, zwłaszcza w kwestiach polityki socjalnej, to zasadnicze elementy odnośnie polityki zagranicznej i europejskiej nie budziły większych kontrowersji. Układ koalicyjny został podpisany przez liderów trzech partii - CDU, CSU i SPD 27 listopada 2013 r. Dokument zatytułowany „Kształtować przyszłość Niemiec”29 poświęcony został głównie kwestiom gospodarczym. ${ }^{30}$ Zagadnienia polityki migracyjnej znalazły się w szerszym rozdziale „Spójność społeczna”. W umowie zasadniczo potwierdzono dotychczasowe założenia niemieckiej polityki migracyjnej. Chadecy zaakceptowali propozycję socjaldemokratów w zakresie podwójnego obywatelstwa dla dzieci imigrantów urodzonych w Niemczech. W przyszłości będą one mogły zachować obywatelstwo kraju pochodzenia rodziców nie tracąc obywatelstwa niemieckiego. Presja migracyjna wywołana konfliktem syryjskim spowodowała, że również polityka rządu względem uchodźców stała się częścią porozumienia koalicyjnego. Partie potwierdziły humanitarny obowiązek niesienia pomocy osobom zagrożonym w krajach ich pochodzenia, jednak zwrócono uwagę, że obok faktycznych ofiar konfliktów często do Europy, w tym do Niemiec, przybywają osoby, którym ochrona się nie należy. Z tego względu zapowiedziano w umowie wprowadzenie szybszej procedury sprawdzania wniosków azylowych - maksymalnie do trzech miesięcy, tak by można osoby nieuprawnione

${ }^{27}$ A. Pfahl-Traughber, Pegida - eine Protestbewegung zwischen Ängsten und Ressentiments (II), 2016, [online] http://www.bpb.de/politik/extremismus/rechtsextremismus/218681/ pegida-eine-protestbewegung-zwischen-aengsten-und-ressentiments-ii, [dostęp 12.06.2016].

${ }^{28}$ E. Stasik, Założyciel Pegidy stanie przed sadem za podżeganie mas, Portal Deutsche Welle, 2016, http://www.dw.com/pl/za\%C5\%82o\%C5\%BCyciel-pegidy-stanie-przed-s\%C4\%85dem-za -pod\%C5\%BCeganie-mas/a-19116330, [dostęp 12.05.2016]

${ }^{29}$ Deutschlands Zukunft gestalten 2013, Koalitionsvertrag zwischen CDU, CSU und SPD, 2013, https://www.cdu.de/sites/default/files/media/dokumente/koalitionsvertrag.pdf, [dostęp 12.05.2016].

${ }^{30}$ P. Kubiak, O krok od wielkiej koalicji. Umowa koalicyjna CDU/CSU-SPD podpisana, „Biuletyn Instytutu Zachodniego” 2013, nr 149, http://www.iz.poznan.pl/uploads/pracownicy/ kubiak/785_umowa_koalicyjna.pdf, [dostęp 12.05.2016]. 
deportować z Niemiec. Kwestią różniącą partie w zakresie polityki azylowej był tzw. obowiązek zamieszkania (niem. Residenzpflicht) dla osób ubiegających się o przyznanie statusu uchodźcy. SPD opowiadała się za zniesieniem tego obowiąz$\mathrm{ku}$, uznając go za ograniczenie praw i wolności człowieka. Tymczasem chadecy byli za jego utrzymaniem, gdyż, ich zdaniem, zapewnia kontrolę nad osobami, których status prawny nie jest jeszcze rozstrzygnięty. W umowie koalicyjnej zapowiedziano, że odpowiednie regulacje w tym zakresie będą w gestii poszczególnych krajów związkowych. W ten sposób osiągnięto kompromis - w landach, w których rządzą socjaldemokraci będą mogli podjąć decyzję o zniesieniu lub modyfikacji Residenzpflicht. Ponadto zaznaczono, że w żadnym wypadku obowiązek ten nie może być przeszkodą, np. w edukacji. Umowa przewiduje także, że osoby ubiegające się o azyl będą mogły podjąć pracę po trzymiesięcznym okresie pobytu na terenie Niemiec.

\section{PODSUMOWANIE}

O ile w obliczu aktualnej presji migracyjnej w wielu państwach europejskich, np. w Polsce, Czechach, na Węgrzech, trwa licytacja polityczna, która partia będzie bardziej antyimigrancka, o tyle w Niemczech partie polityczne podchodzą do tej kwestii dużo spokojniej i bardziej pragmatycznie. Dane statystyczne pokazują, że od 2013 r. następuje stały wzrost liczby wniosków o przyznanie azylu składanych w Niemczech.

Tab. 2. Liczba wniosków o azyl w Niemczech w latach 2013-2016 (do końca lipca).

\begin{tabular}{|l|c|}
\hline \multicolumn{1}{|c|}{ Rok } & Liczba wniosków o azyl \\
\hline 2013 & 109580 \\
\hline 2014 & 172072 \\
\hline 2015 & 441899 \\
\hline 2016 (do końca lipca) & 468762 \\
\hline
\end{tabular}

Źródło: Anzahl der Asylanträge (Erstanträge) in Deutschland von 1991 bis 2016, http://de.statista.com/ statistik/daten/studie/154286/umfrage/asylantraege-erstantraege-in-deutschland-seit-1995/, [dostęp 2.08.2016].

Podobna presja migracyjna miała miejsce w Niemczech także w latach 90. XX wieku, kiedy w wyniku wojen bałkańskich tysiące ludzi opuściło miejsca swojego zamieszkania i szukało bezpiecznego schronienia w Niemczech. Być może pamięć tamtej migracji powoduje, że niemieccy politycy oraz obywatele nie zamykają się na nowych migrantów. Jednak sytuacja może być o tyle odmienna, że większość uchodźców z Bałkanów po zakończeniu konfliktu powróciła do swoich domów, a tym razem takiej pewności nie ma. Co więcej, istnieją również różnice kulturowe między migrantami z Bałkanów a migrantami z Bliskiego Wschodu. Ten argument już stał się jednym z elementów debaty publicznej i bywa wykorzystywany przez 
skrajne środowiska polityczne, a negatywne zdarzenia z udziałem migrantów ${ }^{31}$ tylko potęgują siłę tego argumentu. ${ }^{32}$ Rząd realizując postanowienia zawarte $\mathrm{w}$ umowie koalicyjnej stara się jednocześnie zachować pewną elastyczność i odpowiadać na społeczne oczekiwania. 23 października 2015 r. wszedł w życie tzw. I pakiet azylowy, który miał na celu częściowe ograniczenie migracji. Pakiet zakładał m.in. możliwość dokonywania deportacji osób, którym nie przyznano statusu uchodźcy, ani nie objęto ochroną uzupełniającą, bez wcześniejszego podania terminu. Ma to na celu zapobieżenie sytuacjom, gdy osoba mająca podlegać deportacji znikała. Kolejny punkt zakładał możliwość relokacji nieletnich pozbawionych opieki. Chodziło o to, by młodociani od razu podlegali socjalizacji w społeczeństwie niemieckim. Oba powyższe rozwiązania spotkały się z ostrą krytyką obrońców praw człowieka, jako przejaw nieludzkiego traktowania - w pierwszym przypadku argumentem było tworzenie poczucia niepewności i strachu, a $\mathrm{w}$ drugim zrywanie więzi nieletnich z ich naturalnym środowiskiem i społecznością, z której pochodzili. Pakiet rozszerzał także listę krajów bezpiecznych o państwa bałkańskie - Kosowo, Czarnogórę i Albanię, co daje możliwość odsyłania migrantów, aby tam czekali na rozpatrzenie wniosków azylowych. 29 stycznia 2016 r. koalicja uzgodniła II pakiet azylowy, który miał uzupełnić rozwiązania przyjęte jesienią poprzedniego roku. Do listy krajów bezpiecznych dodano państwa Maghrebu - Tunezję, Maroko i Algierię. Jednak najwięcej kontrowersji wzbudziło rozwiązanie dotyczące wprowadzenia dwuletniego memorandum na prawo łączenia rodzin dla osób, które nie były osobiście i bezpośrednio prześladowane. Ten przepis dotyczy także dzieci i młodocianych, które nie będą mogły sprowadzić swoich rodziców. Tym razem największa krytyka spadła na socjaldemokratów, którym zarzucono brak wrażliwości społecznej, choć

${ }^{31}$ Jednym z najbardziej nagłośnionych zdarzeń z udziałem migrantów z Bliskiego Wschodu była seria napaści seksualnych na kobiety m.in. w Kolonii w noc sylwestrową 2015 r. Bulwersujące w całej sprawie było także zachowanie, a właściwie brak reakcji, policji na pierwsze doniesienia o aktach molestowania kobiet. Cała sprawa wywołała debatę ogólnoniemiecką na temat różnic kulturowych i bezpieczeństwa w kontekście masowego napływu migrantów, M. Eddy, Attacks on German Women Inflame Debate on Migrants, 5 January 2016, NYT online, http://www.nytimes. com/2016/01/06/world/europe/coordinated-attacks-on-women-in-cologne-were-unprecedented -germany-says.html?_r=0, [dostęp 12.05.2016]. W wyjaśnienie wydarzeń z Kolonii zaangażowała się bezpośrednio kanclerz A. Merkel i jej ministrowie, Übergriffe in Köln: Merkel verlangt harte Antwort des Rechtsstaats, Der Spiegel Online z 5.01.2016, http://www.spiegel.de/politik/deutschland/ koeln-angela-merkel-verlangt-harte-antwort-des-rechtsstaats-a-1070609.html, [dostęp 12.05.2016]. Niemniej na portalach i stronach internetowych partii skrajnie prawicowych pojawiła się fala krytyki wobec rządu i prezentowanej przez niego Willkommenskultur wobec migrantów, J. Meuthen, Politik erteilt nordafrikanischen Banden in deutschen Großstädten einen Freibrief, 2016, https:// www.alternativefuer.de/meuthen-politik-erteilt-nordafrikanischen-banden-in-deutschen-grossstaedten-einen-freibrief/, [dostęp 12.05.2016].

${ }^{32} \mathrm{~S}$. Weiland, Rechte Hetze: Wie die AfD die Übergriffe von Köln instrumentalisiert, Der Spiegel Online z 8.01.2016, http://www.spiegel.de/politik/deutschland/koeln-afd-instrumentalisiert-uebergriffe-politisch-a-1070895.html, [dostęp 12.05.2016]. 
w ich programie partyjnym prawa człowieka zajmują ważne miejsce. ${ }^{33}$ Niemniej, mimo wprowadzenia szeregu ograniczeń i restrykcji, poziom migracji w 2016 r. nie zmniejszył się, czego dowodzą statystyki, wedle których w pierwszej połowie tego roku złożono więcej wniosków o udzielenie azylu niż w całym roku poprzednim.

Reasumując i odpowiadając jednocześnie na pytania badawcze sformułowane we wstępie, należy zauważyć, że niemiecka scena polityczna w obliczu kryzysu migracyjnego nie doznała wstrząsu. Poszczególne partie parlamentarne, w tym główne ugrupowania - CDU/CSU i SPD, ale także Zieloni i Lewica nie zrewidowały zasadniczo swoich programów zachowując wcześniejsze poglądy w odniesieniu do polityki migracyjnej. Wskazuje to $\mathrm{z}$ jednej strony na dużą stabilność samych partii, a z drugiej strony stabilność elektoratów tych partii. Pewnym zagrożeniem dla konsensualnej polityki niemieckiej było pojawienie się na scenie nowej siły politycznej w postaci Alternatywy dla Niemiec. Można uznać, że dwa pakiety azylowe zostały przyjęte przez rząd Angeli Merkel jako próba pozbawienia AfD argumentu o zbyt liberalnej polityce wobec migrantów. Dopiero kolejne wybory federalne mogą dać odpowiedź na pytanie, na ile Alternatywa stanie się realną siłą polityczną, z której programem pozostałe partie będą musiały się liczyć. Wynik wyborów w 2013 r. paradoksalnie wzmocnił konsensus polityczny w Niemczech, także w dziedzinie migracji. Sytuacja, w której dwie największe siły polityczne - chadecja i socjaldemokracja, zostały przez werdykt wyborców zmuszone do współpracy, sprawia, że rząd realizuje kompromisowy program, uwzględniający oczekiwania dużych grup społecznych. Dodatkowo, rząd ma szerokie zaplecze polityczne, a z drugiej strony siła opozycji - parlamentarnej i pozaparlamentarnej jest niewielka. Tak więc nic nie zapowiada, by w najbliższej przyszłości konsensualny charakter polityki niemieckiej miał ulec gwałtownym przeobrażeniom.

\title{
Title: German Political Groups Towards Refugee Crisis
}

\begin{abstract}
The Federal Republic of Germany has developed a model of integration and assimilation of refugees and economic migrants, which for decades was a model for other European countries and the European Union (EU). This was possible thanks to the consensus between the main political forces in the country, which, despite the natural alternation of power, do not undermine the main objectives of both foreign policy as well as internal, including the approach to immigrants. The situation changed after 2011 and the events in North Africa, known as the Arab Spring, the consequence of which was a massive influx of refugees and immigrants to Germany. This article examines the position of the main political parties in relation to the refugee crisis.
\end{abstract}

Key words: Germany; migration policy; refugee crisis; the Arab Spring; German political parties

${ }^{33}$ R. Romaniec, Niemiecka prasa: nowy pakiet azylowy pozbawia dzieci i młodocianych podstawowych praw, Portal Deutsche Welle, 2016, http://www.dw.com/pl/niemiecka-prasa-nowy-pakiet-azylowy-pozbawia-dzieci-i-m\%C5\%82odocianych-podstawowych-praw/a-19032569, [dostęp 10.08.2016]. 